\title{
Occurrence and Distribution of Pumpkin and Squash Viruses in Illinois
}

\author{
S. Jossey and M. Babadoost, Department of Crop Sciences, University of Illinois, Urbana 61801
}

\begin{abstract}
Jossey, S., and Babadoost, M. 2008. Occurrence and distribution of pumpkin and squash viruses in Illinois. Plant Dis. 92:61-68.
\end{abstract}

Surveys were conducted during 2004 to 2006 to identify the viruses infecting pumpkin and squash in Illinois. In 2004, 16 jack-o-lantern pumpkin (Cucurbita pepo) samples and one squash (C. pepo) sample were collected from 11 counties. In 2005, 85 jack-o-lantern pumpkin, 12 processing pumpkin (Cucurbita moschata), 37 squash, and six gourd (C. pepo) samples were collected from 54 counties. In 2006, 85 jack-o-lantern pumpkin, 16 processing pumpkin, 51 squash, and 18 gourd samples were collected from 47 counties. Cucumber mosaic virus (CMV), Papaya ringspot virus (PRSV), Squash mosaic virus (SqMV), Tobacco ringspot virus (TRSV), Tomato ringspot virus (ToRSV), Watermelon mosaic virus (WMV), Zucchini yellow mosaic virus (ZYMV), and unknown potyviruses were detected in pumpkin, squash, and gourd fields during the surveys, using enzyme-linked immunosorbent assay (ELISA). Overall, 86, 11, 75, and 79\% of jack-o-lantern pumpkin, processing pumpkin, squash, and gourds, respectively, were tested positive for virus infection during the survey. WMV was detected in 47,46 , and $52 \%$ of the samples in 2004, 2005, and 2006, respectively, and was the most prevalent virus throughout the state. SqMV was detected in more counties than any other virus because it was identified in 65 and $88 \%$ of the counties surveyed in 2005 and 2006, respectively. SqMV was detected in 6, 41, and $48 \%$ of the samples in 2004, 2005, and 2006, respectively. During the surveys, CMV was detected in 6,4 , and $3 \%$ of the samples; PRSV was detected in 6,11 , and $4 \%$ of the samples; and ZYMV was detected in 18, 4, and $4 \%$ of the samples tested in 2004, 2005, and 2006, respectively. TRSV was detected in $3 \%$ of the samples in 2005, for the first time on pumpkin in Illinois. Pathogenicity of the detected viruses was proved for CMV, PRSV, SqMV, WMV, and ZYMV on summer squash ('Fortune' and 'Grey Zucchini'), jack-o-lantern pumpkin ('Howden'), and processing pumpkin ('Dickinson'). All of the viruses were present alone and mixed in the samples tested. Earlier in the growing seasons (July and early August), single-virus infections were detected. Mixed infections were more common from the second week of August until the end of the growing season in October. Dual infection of WMV and SqMV was the most prevalent mixed virus infection detected in Illinois. Most viruses infecting pumpkin and squash showed similar symptoms. The most common symptoms observed in the commercial fields and in the greenhouse studies were light- and dark-green mosaic, veinbanding, veinclearing, puckering, and deformation of leaves of pumpkin, squash, and gourds. Severe symptoms included fernleaf and shoestring on leaves and color breaking and deformation of fruit.

Additional keywords: cucurbits, RT-PCR

Illinois is the leading state in pumpkin production in the United States. Approximately 4,800 ha of jack-o-lantern pumpkin (Cucurbita pepo L.) and 4,000 ha of processing pumpkin (Cucurbita moschata Poir.), representing more than $90 \%$ of processing pumpkin produced in the United States, are grown annually in Illinois (2). Also, about 3,200 ha of other cucurbit crops, including cucumber (Cucumis sativus L.), gourds ( $C$. pepo), melon (Cucumis melo L. and Citrullus lanatus (Thunb.) Matsum. \& Nakai), and squash (Cucurbita pepo) are grown annually in Illinois (2).

Diseases caused by viruses are among the serious threats to cucurbit production

Corresponding author: M. Babadoost
E-mail: babadoos@uiuc.edu

Accepted for publication 13 August 2007.

doi:10.1094/PDIS-92-1-0061

(c) 2008 The American Phytopathological Society
States (18). Squash leaf curl virus (SLCV; genus Begomovirus, family Geminiviridae) has been reported on cucurbits from Arizona, California, and Texas $(3,17)$. In a study conducted in southern Illinois, WMV was reported to be the most prevalent cucurbit virus (27). In addition, CMV, PRSV, SqMV, and ZYMV were detected to cause mixed infections with WMV late in the season in southern Illinois.

Virus symptoms on cucurbit vary from mild mosaic or veinbanding to severe systemic mosaic and malformation of leaves, color change and deformation of fruit, and plant stunting $(4,15,23)$. Severity of the symptoms on fruit depends on the stage of fruit development at the time of infection (19). PRSV and ZYMV have been reported to cause mosaic, plant stunting, and malformation of foliage such as blistering and shoestring symptom (4). CMV, PRSV, SqMV, TRSV, and WMV have been reported to induce systemic mottling with leaf malformation in squash (28). In squash and pumpkin, SLCV induced leaf curl and mosaic symptoms (3).

Detection of CMV, PRSV, SLCV, SqMV, WMV, and ZYMV in cucurbits has been achieved by utilizing alkaline phosphatase enzyme-linked immunosorbent assay (ELISA) kits (18,27). Reversetranscription polymerase chain reaction (RT-PCR) also has been used for detection of TRSV and ToRSV by amplification of a conserved coat protein region (12). Pathogenicity testing of CMV, PRSV, SqMV, WMV, and ZYMV has been carried out by extracting plant sap in potassium phosphate buffer and inoculating the sap onto Carborundum-dusted leaves of summer squash ('Grey zucchini') plants $(4,18)$. The presence of the virus is confirmed in the inoculated plants after symptom expression by ELISA.

The objective of this study was to determine the incidence of viral diseases in pumpkin and squash in Illinois for the goal of developing effective strategies for their management.

\section{MATERIALS AND METHODS}

Surveys. Surveys were conducted in 2004, 2005, and 2006 to determine viruses associated with pumpkin and squash crops in Illinois. In 2004, 16 jack-o-lantern pumpkin samples and one squash sample were collected from 11 randomly selected counties in August and September (Fig. 1). Sample collections in 2005 and 2006 were carried out after dividing the 102 counties in the state into four regions: northeast, southeast, southwest, and northwest (Fig. 2). 
In 2005, 85 jack-o-lantern pumpkin, 12 processing pumpkin, 37 squash, and six gourd samples were collected from 54 counties (Fig. 3) during June to October. Number of counties surveyed in the northeastern, southeastern, southwestern, and northwestern regions was $13,14,14$, and 13 , respectively. In 2006, 85 jack-o-lantern pumpkin, 16 processing pumpkin, 51 squash, and 18 gourd samples were collected from 47 counties (Fig. 4) during July to September. Number of counties surveyed in the northeastern, southeastern, southwestern, and northwestern regions was $11,8,11$, and 17 , respectively.

Sample collection. Samples from pumpkin, squash, and gourd plants were collected from 10 different spots within each field by walking diagonally in the field. At each spot, at least two leaves exhibiting virus symptom and at least one six-inch growing vine tip were collected. If no symptoms were evident in the field at the time of sample collection, younger leaves and growing vine tips of the plants were collected from 10 locations as described above.

The collected samples were placed in plastic bags and labeled. The samples then were transported to the laboratory at the coolest possible conditions (close to $4^{\circ} \mathrm{C}$ ) on the same day or shipped overnight after cooling at $4{ }^{\circ} \mathrm{C}$ for at least $2 \mathrm{~h}$. Upon reaching the laboratory, the samples were immediately placed at $4{ }^{\circ} \mathrm{C}$ and were assayed for the virus or inoculated onto healthy plants for symptom development within a week. The samples collected also were stored in plastic bags at -20 or $-80^{\circ} \mathrm{C}$ for later studies.

Determining incidence of virus infection during the growing season. In 2006, samples were collected monthly from selected commercial fields to determine the viruses present during the various growth stages of jack-o-lantern pumpkin, process- ing pumpkin, and squash. The samples of jack-o-lantern pumpkin and squash were collected from one field each in Kankakee County (in northern Illinois), Champaign County (in central Illinois), and Gallatin County (in southern Illinois). Processing pumpkin samples were collected from three fields in Tazewell County in central Illinois. The samples were collected during June, July, August, and September according to the above-mentioned procedures and tested immediately.

Symptomatology. The symptoms observed on the leaves, vines, and fruit were recorded at the time of sample collection. The cultivars and the distribution of the infected plants in the field also were recorded for each sample collected. Additional notes on the symptoms also were recorded in the laboratory, as needed.

Virus detection and identification. The collected samples were tested for CMV, PRSV, SqMV, TRSV, ToRSV, WMV, and



Fig. 1. Counties in Illinois where Cucumber mosaic virus (CMV), Papaya ringspot virus (PRSV), Squash mosaic virus (SqMV), Tomato ringspot virus (ToRSV), Watermelon mosaic virus (WMV), and Zucchini yellow mosaic virus (ZYMV) were detected in jack-o-lantern pumpkin samples in 2004.

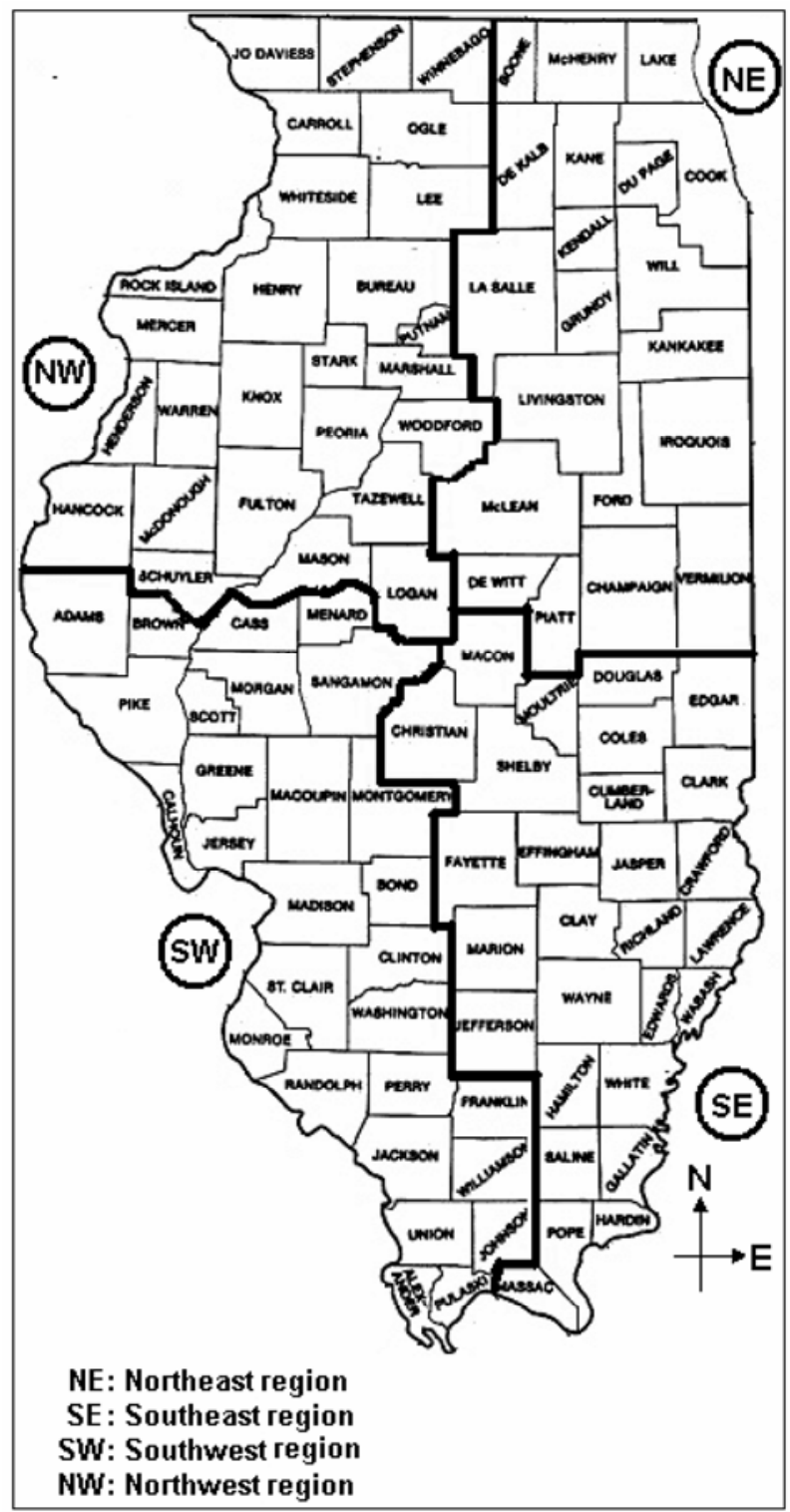

Fig. 2. Four-region divisions of Illinois for surveying pumpkin, squash, and gourd fields for incidence of viruses in 2005 and 2006. 
ZYMV, utilizing double-antibody sandwich (DAS)-ELISA kits from Agdia Inc. (Elkhart, IN). Potyviruses were detected using the indirect ELISA kit from Agdia Inc. that detects most aphid-transmitted potyviruses. In 2005 and 2006, 40 and 48 randomly selected samples, respectively, were tested for the presence of SLCV, utilizing a triple-antibody sandwich (TAS)ELISA kit from Neogen Europe (Scotland, UK).

Three subsamples from each sample were tested for CMV, PRSV, SqMV, TRSV, ToRSV, WMV, ZYMV, and genus Potyvirus. Each subsample (1 to $2 \mathrm{~g}$ ) consisted of parts from 5 to 10 different leaves and parts of two vine tips. Only two subsamples from each of the randomly selected samples were tested for SLCV.
DAS-ELISA was conducted by extracting plant sap by grinding the subsample and diluting the sap in extraction buffer (provided with the DAS-ELISA kit, Agdia Inc.) at a ratio of 1:10 (vol/vol, sap:buffer). This sap was loaded randomly into the polyclonal anti-virus antibody-coated wells. The wells were incubated at $4^{\circ} \mathrm{C}$ for $12 \mathrm{~h}$, washed using phosphate-buffered saline Tween (PBST) (provided with the DAS-ELISA kit, Agdia Inc.), and dried on paper towels. The washed and dried wells were loaded with alkaline phosphataseconjugated anti-virus antibody and incubated at room temperature $\left(23^{\circ} \mathrm{C}\right)$ for $2 \mathrm{~h}$. The wells were washed and loaded with $p$ nitrophenol phosphate (substrate for the enzyme alkaline phosphatase) and incubated at room temperature $\left(23^{\circ} \mathrm{C}\right)$ for 30 min. The reaction was measured using a spectrophotometer (Multiskan Ascent, Labsystems, Helsinki, Finland) at $405 \mathrm{~nm}$ and also confirmed visually. Samples were considered positive for virus in ELISA if the absorbance reading at $405 \mathrm{~nm}$ was equal to or more than $3 \times$ the absorbance of the negative control. Positive controls from Agdia Inc. for each virus were included in every ELISA. Negative controls consisting of one well of extract from healthy pumpkin or squash tissue and one well of ELISA extraction buffer also were included in every ELISA.

Testing for pathogenicity. The samples from which the viruses were detected also were tested for pathogenicity by inoculating onto jack-o-lantern pumpkin ('Howden'), processing pumpkin ('Dickinson'),

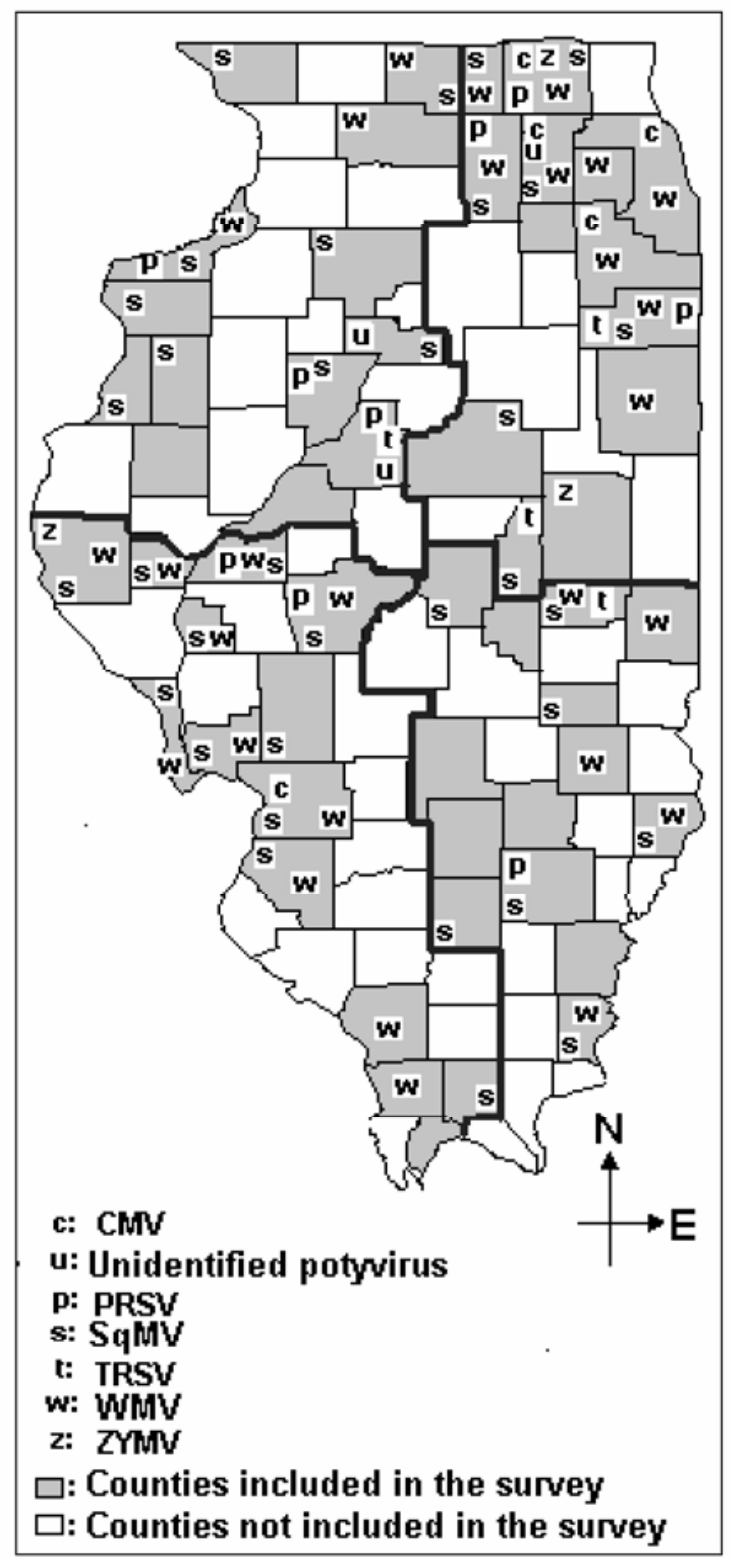

Fig. 3. Counties in Illinois where Cucumber mosaic virus (CMV), unidentified potyviruses, Papaya ringspot virus (PRSV), Squash mosaic virus (SqMV), Tobacco ringspot virus (TRSV), Watermelon mosaic virus (WMV), and Zucchini yellow mosaic virus (ZYMV) were detected in pumpkin, squash, and gourd samples in 2005.



Fig. 4. Counties in Illinois where Cucumber mosaic virus (CMV), unidentified potyviruses, Papaya ringspot virus (PRSV), Squash mosaic virus (SqMV), Tobacco ringspot virus (TRSV), Watermelon mosaic virus (WMV), and Zucchini yellow mosaic virus (ZYMV) were detected in pumpkin, squash, and gourd samples in 2006. 
and summer squash ('Fortune' and 'Grey Zucchini'). The samples were ground in cold $0.025 \mathrm{M}$ potassium phosphate buffer, $\mathrm{pH} 7.1$, with $0.01 \mathrm{M}$ sodium sulfite and spread with cheese cloth onto two- to three-leaf-stage seedlings, which were dusted with Carborundum prior to the inoculation. The inoculated plants were rinsed with water and maintained in a greenhouse for 4 weeks at day temperatures ranging from 23 to $25^{\circ} \mathrm{C}$, night temperatures ranging from 21 to $23^{\circ} \mathrm{C}$, and a photoperiod from 6:00 a.m. to 9:00 p.m., to allow symptom development. The presence of viruses was verified in the plants using ELISA.

Molecular diagnosis. RT-PCR was used to detect TRSV and ToRSV (12). The primers for TRSV and ToRSV were designed for the conserved regions in the coat protein gene of different TRSV strains in the GenBank database (SDSC Biology Workbench). The conserved regions were identified using the multiple sequence alignment program ClustalW. Primers were designed using the program Primer3 (SDSC Biology Workbench) for these conserved sequence. The primers used for the detection of TRSV were CTTGCG GCCCAAATCTATAA and ACTTGTGCC CAGGAGAGCTA and for ToRSV were CATGGGCGCATTAAAAAGAT and AAG TGGTTGCACTGTTGACG to produce a product of 348 and $609 \mathrm{bp}$, respectively.

The RT-PCR was conducted on total RNA extracted from 50 to $100 \mathrm{mg}$ of symptomatic leaf using TRIzol reagent (Invitrogen, Carlsbad, CA). The TRIzol reagent was added to ground leaf samples, mixed thoroughly, and incubated at $23^{\circ} \mathrm{C}$ for $5 \mathrm{~min}$. Chloroform was added to the mixture and centrifuged at $12,000 \times g$ for $15 \mathrm{~min}$ at $4^{\circ} \mathrm{C}$ for the formation of aqueous phase. The RNA then was recovered from the aqueous phase by precipitation with isopropyl alcohol. The RNA collected was washed in $75 \%$ ethanol, dissolved in sterile double-distilled water at $60^{\circ} \mathrm{C}$, and stored at $-80^{\circ} \mathrm{C}$. c-DNA was produced by reverse transcription with M-MLV Reverse Tran- scriptase (Invitrogen) using the abovementioned reverse primers, and RNase inhibitor RNaseOUT (Invitrogen) according to the instructions in the M-MLV-RT kit.

The PCR was done by initial denaturing of c-DNA at $94^{\circ} \mathrm{C}$ for $30 \mathrm{~s}$; followed by 35 cycles of $94^{\circ} \mathrm{C}$ for $30 \mathrm{~s}, 58^{\circ} \mathrm{C}$ for TRSV or $57^{\circ} \mathrm{C}$ for ToRSV for $45 \mathrm{~s}$, and $72^{\circ} \mathrm{C}$ for 1 min; with a final extension period of DNA at $72^{\circ} \mathrm{C}$ for $10 \mathrm{~min}$. The RT-PCR product from TRSV samples and HyperladerV ladder (Bioline USA Inc., Randolph, MA) were loaded on a $3.5 \%$ agarose gel and the product of ToRSV sample amplification and the TrackIt 100-bp DNA ladder (Invitrogen) were loaded on a $1 \%$ agarose gel. A positive control consisting of RNA extracted from a TRSV-infected plant sample or RNA extracted from a lyophilized ToRSV-infected plant sample were used for detecting TRSV and ToRSV, respectively. Negative control consisting of a healthy pumpkin or squash sample also was included in all of the RT-PCR conducted.

The Potyvirus sp. that was not identified as PRSV, WMV, and ZYMV also was detected using RT-PCR. RT-PCR was done with primers RCF1 and one of the forward primers Poty4 or primer Poty4.1 designed for the conserved region of the nuclear inclusion-b (Nib) protein as previously described (21). Other degenerate primers designed for the conserved Nib region, forward primer PVD-1 (9), reverse primer FM10820 (25), and primers MJ1 and MJ2 (14) also were used in Potyvirus sp. detection.

\section{RESULTS}

Viruses identified. Viruses detected in the pumpkin, squash, and gourd fields surveyed in 2004, 2005, and 2006, were CMV, PRSV, SqMV, TRSV, ToRSV, WMV, ZYMV, and unknown potyviruses. ToRSV was detected in only one jack-olantern pumpkin sample in 2004 and TRSV was detected in jack-o-lantern pumpkin and processing pumpkin samples only in 2005 . Overall, 86, 11, 75, and 79\% of jack-o-lantern pumpkin, processing pumpkin, squash, and gourds, respectively, were tested positive for virus infection during the survey.

Distribution of viruses. $C M V$. In 2004, CMV was detected in one jack-o-lantern pumpkin sample from McHenry County as a single-virus infection (Table 1; Fig. 1). In 2005, CMV was identified in five samples collected from Cook, Kane, McHenry, and Will counties in the northeastern region and Madison County in the southwestern region (Table 2; Fig. 3). CMV was detected as a single-virus infection in two samples, mixed infection of two viruses (CMV and WMV) in two samples, and mixed infection of four viruses (CMV, PRSV, SqMV, and ZYMV) in one sample (Table 2). In 2006, CMV was detected in five samples from Kane and McHenry counties (northwestern region) and Madison County (southwestern region) (Table 3; Fig. 4). Mixed infections of CMV with WMV were identified in three samples and infections of CMV with WMV and SqMV were detected in two samples (Table 3).

PRSV. In 2004, PRSV was detected in a single jack-o-lantern pumpkin sample collected from Champaign County as a mixed infection with ZYMV (Table 1; Fig. 1). In 2005, PRSV was identified in 15 samples from McHenry, Dekalb, and Kankakee counties in the northeastern region; Wayne County in the southeastern region; Cass and Sangamon counties in the southwestern region; and Tazewell, Peoria, and Rock Island counties in the northwestern region (Fig. 3). PRSV was detected as a single-virus infection in six samples, two-virus mixed infection of PRSV with WMV in two samples, and two-virus mixed infection of PRSV with SqMV in four samples. Three-virus mixed infection of PRSV with WMV and SqMV was detected in two samples and a four-virus mixed infection of PRSV with CMV, SqMV, and ZYMV was detected in one sample (Table 2). In 2006, PRSV was identified in seven samples tested from

Table 1. Incidence of viruses in pumpkin, squash, and gourd fields in Illinois in $2004^{\mathrm{a}}$

\begin{tabular}{|c|c|c|c|c|c|c|c|c|c|}
\hline \multirow[b]{2}{*}{ Detected $^{\text {d }}$} & \multirow[b]{2}{*}{ No. of counties ${ }^{e}$} & \multicolumn{2}{|c|}{ Samples with virus } & \multicolumn{4}{|c|}{ Number of infected samples $(\%)^{b}$} & \multicolumn{2}{|c|}{ Total number of samples ${ }^{c}$} \\
\hline & & Number & Percent & J-o-l & Proc. & Squash & Gourd & Single $(\%)$ & Mixed (\%) \\
\hline CMV & 1 & 1 & 6 & $1(6)$ & 0 & 0 & 0 & $1(6)$ & 0 \\
\hline Potyviruses & 0 & 0 & 0 & 0 & 0 & 0 & 0 & 0 & 0 \\
\hline PRSV & 1 & 1 & 6 & $1(6)$ & 0 & 0 & 0 & $1(6)$ & 0 \\
\hline SqMV & 1 & 1 & 6 & $1(6)$ & 0 & 0 & 0 & $1(6)$ & 0 \\
\hline ToRSV & 1 & 1 & 6 & $1(6)$ & 0 & 0 & 0 & 0 & $1(6)$ \\
\hline TRSV & 0 & 0 & 0 & 0 & 0 & 0 & 0 & 0 & 0 \\
\hline WMV & 4 & 8 & 47 & $8(50)$ & 0 & 0 & 0 & $6(35)$ & $2(12)$ \\
\hline ZYMV & 3 & 3 & 18 & $3(19)$ & 0 & 0 & 0 & $1(6)$ & $2(12)$ \\
\hline
\end{tabular}


Champaign and Iroquois counties (northeastern region), Moultrie County (southeastern region), and Whiteside County (northwestern region) (Table 3; Fig. 4). Single-virus infection of PRSV was detected in two samples, two-virus mixed infection of PRSV with SqMV was recorded in two samples, three-virus mixed infection of PRSV with WMV and SqMV was detected in one sample, and threevirus mixed infection of PRSV with WMV and ZYMV was detected in two samples (Table 3).

Potyvirus genus. In 2005, unknown potyviruses, serologically distinct from PRSV, WMV, and ZYMV, were detected in three jack-o-lantern and processing pumpkin samples. Infected samples had been collected from Kane County in the northeastern region and Marshall and Tazewell counties in the northwestern region (Table 2; Fig. 3). In 2006, Potyvirus assays detected serologically distinct potyviruses from PRSV, WMV, and ZYMV in eight jack-o-lantern pumpkin, processing pumpkin, and squash samples from Kankakee and Will counties in the northeastern region; Jackson, Randolf, and Williamson counties in the southwestern region; and Henderson County in the northwestern region (Table 3; Fig. 4). Infection of the unknown potyviruses alone was detected in three samples, and mixed infection of the potyviruses with SqMV was detected in five samples (Table 3). The results from ELISA were not confirmed by RT-PCR because the different primers used failed to produce the desired size of PCR-products.

SqMV. In 2004, SqMV was detected in only one jack-o-lantern pumpkin sample tested, which was as a single-virus infection from Dekalb County (Table 1; Fig. 1). In 2005, 57 samples representing 34 counties (63\% of counties surveyed) throughout the state were found infected with SqMV (Table 2; Fig. 3). Single-virus infection of SqMV was detected in 27 samples. Twovirus mixed infection of SqMV with WMV was detected in 21 samples, mixed infection of SqMV with PRSV was detected in four samples, and mixed infection of SqMV with TRSV was detected in two samples. Three-virus mixed infection of SqMV, WMV, and PRSV was detected in two samples and four-virus mixed infection of SqMV, PRSV, ZYMV, and CMV was detected in one sample. In 2006, SqMV was detected in 81 samples collected from 38 counties $(81 \%$ counties surveyed) throughout the state (Table 3; Fig. 4). Single-virus infection of SqMV was identified in 20 samples. Mixed-virus infection of SqMV with CMV was detected in one sample, SqMV with unidentified potyviruses was determined in five samples, SqMV with PRSV was detected in two samples, and SqMV with WMV was detected in 50 samples $(29 \%$ of samples tested). Three-virus mixed infection of SqMV, ZYMV, and WMV was detected in two samples and mixed infection of SqMV, CMV, and WMV was determined in one sample.

TRSV. TRSV was detected in three jack-o-lantern and one processing pumpkin samples in 2005 for the first time in Illinois (13). The virus was detected in samples collected from Kankakee and Piatt

Table 2. Incidence of viruses in pumpkin, squash, and gourd fields in Illinois in $2005^{\mathrm{a}}$

\begin{tabular}{|c|c|c|c|c|c|c|c|c|c|}
\hline \multirow[b]{2}{*}{ Detected $^{\mathrm{d}}$} & \multirow[b]{2}{*}{ No. of counties ${ }^{e}$} & \multicolumn{2}{|c|}{ Samples with virus } & \multicolumn{4}{|c|}{ Number of infected samples $(\%)^{b}$} & \multicolumn{2}{|c|}{ Total number of samples } \\
\hline & & Number & Percent & J-o-I & Proc. & Squash & Gourd & Single (\%) & Mixed (\%) \\
\hline $\mathrm{CMV}$ & 5 & 5 & 4 & $2(2)$ & 0 & $3(8)$ & 0 & $2(2)$ & $3(2)$ \\
\hline Potyviruses & 3 & 3 & 2 & 0 & $1(8)$ & $2(5)$ & 0 & $3(2)$ & 0 \\
\hline PRSV & 9 & 15 & 11 & $6(7)$ & $1(8)$ & $6(16)$ & $2(33)$ & $6(4)$ & $9(6)$ \\
\hline SLCV $^{f}$ & 0 & 0 & 0 & 0 & 0 & 0 & 0 & 0 & 0 \\
\hline SqMV & 34 & 57 & 41 & $42(49)$ & 0 & $14(38)$ & $1(17)$ & $27(19)$ & $30(22)$ \\
\hline ToRSV & 0 & 0 & 0 & 0 & 0 & 0 & 0 & 0 & 0 \\
\hline TRSV & 4 & 4 & 3 & $3(4)$ & $1(8)$ & 0 & 0 & $2(1.5)$ & $2(1.5)$ \\
\hline WMV & 28 & 64 & 46 & $43(51)$ & 0 & $16(43)$ & $5(83)$ & $36(26)$ & $28(20)$ \\
\hline ZYMV & 3 & 5 & 4 & $3(4)$ & 0 & $2(5)$ & 0 & $3(2)$ & $2(1)$ \\
\hline
\end{tabular}

a In 2005, 85 jack-o-lantern pumpkin, 12 processing pumpkin, 37 squash, and six gourd samples (140 samples in all) were collected and tested.

b J-o-1 = jack-o-lantern pumpkin samples, Proc. = processing pumpkin samples, and Squash = summer and winter squash samples.

c Number and percent of samples with single virus or mixed viruses. Mixed $=$ two or more viruses were detected in the same sample.

d Viruses were detected using enzyme-linked immunosorbent assay (ELISA) kits (Agdia, Inc., Elkhart, IN), except for Squash leaf curl virus (SLCV) that was tested using ELISA kits from Neogen Europe (Scotland, UK): Cucumber mosaic virus (CMV), Papaya ringspot virus (PRSV), Squash mosaic virus (SqMV), Tomato ringspot virus (ToRSV), Tobacco ringspot virus (TRSV), Watermelon mosaic virus (WMV), and Zucchini yellow mosaic virus (ZYMV).

e Number of counties with infected samples. Pumpkin, squash, and gourd fields in 54 counties were surveyed for presence of viruses.

f Only 40 randomly selected samples from 28 counties were tested for the presence of SLCV.

Table 3. Incidence of viruses in pumpkin, squash, and gourd fields in Illinois in $2006^{\mathrm{a}}$

\begin{tabular}{|c|c|c|c|c|c|c|c|c|c|}
\hline \multirow[b]{2}{*}{ Detected $^{d}$} & \multirow[b]{2}{*}{ No. of counties ${ }^{e}$} & \multicolumn{2}{|c|}{ Samples with virus } & \multicolumn{4}{|c|}{ Number of infected samples $(\%)^{b}$} & \multicolumn{2}{|c|}{ Total number of samples ${ }^{c}$} \\
\hline & & Number & Percent & J-o-I & Proc. & Squash & Gourd & Single (\%) & Mixed (\%) \\
\hline CMV & 3 & 5 & 3 & $4(5)$ & 0 & $1(2)$ & 0 & 0 & $5(3)$ \\
\hline Potyviruses & 6 & 8 & 5 & $3(4)$ & 0 & $4(8)$ & $1(6)$ & $3(2)$ & $5(3)$ \\
\hline PRSV & 4 & 7 & 4 & $5(6)$ & 0 & $2(4)$ & 0 & $2(1)$ & $5(3)$ \\
\hline $\mathrm{SLCV}^{\mathrm{f}}$ & 0 & 0 & 0 & 0 & 0 & 0 & 0 & 0 & 0 \\
\hline SqMV & 38 & 81 & 48 & $45(53)$ & 0 & $24(47)$ & $12(67)$ & $20(12)$ & $61(36)$ \\
\hline ToRSV & 0 & 0 & 0 & 0 & 0 & 0 & 0 & 0 & 0 \\
\hline TRSV & 0 & 0 & 0 & 0 & 0 & 0 & 0 & 0 & 0 \\
\hline WMV & 37 & 89 & 52 & $58(68)$ & 0 & $20(39)$ & $11(61)$ & $30(17)$ & $59(35)$ \\
\hline ZYMV & 3 & 6 & 4 & $3(4)$ & 0 & $2(4)$ & $1(6)$ & $1(1)$ & $5(3)$ \\
\hline
\end{tabular}

a In 2006, 85 jack-o-lantern pumpkin samples, 16 processing pumpkin samples, 51 squash samples, and 18 gourd samples (170 samples in all) were collected and tested.

b J-o-l = jack-o-lantern pumpkin samples, Proc. = processing pumpkin samples, and Squash = summer and winter squash samples.

${ }^{c}$ Number and percent of samples with single virus or mixed viruses. Mixed $=$ two or more viruses were detected in the same sample.

${ }^{\mathrm{d}}$ Viruses were detected using enzyme-linked immunosorbent assay kits (Agdia, Inc., Elkhart, IN) except for Squash leaf curl virus (SLCV) that was tested using ELISA kits from Neogen Europe (Scotland, UK): Cucumber mosaic virus (CMV), Papaya ringspot virus (PRSV), Squash mosaic virus (SqMV), Tomato ringspot virus (ToRSV), Tobacco ringspot virus (TRSV), Watermelon mosaic virus (WMV), and Zucchini yellow mosaic virus (ZYMV).

e Number of counties with infected samples. Pumpkin, squash, and gourd fields in 47 counties were surveyed for presence of viruses.

f Only 48 randomly selected samples from 41 counties were tested for the presence of SLCV. 
counties in the northeastern region, Douglas County in the southwestern region, and Tazewell County in the northwestern region (Table 2; Fig. 3). Single-virus infection of TRSV was detected in two samples and mixture infection of TRSV with SqMV was recorded in two other samples (Table 2). TRSV was not detected in the samples tested in 2004 and 2006.

ToRSV. ToRSV was detected for the first time in Illinois in 2004 using ELISA. However, detection of ToRSV could not be verified by RT-PCR, which might be due to sample degradation during 18-month storage at $-20^{\circ} \mathrm{C}$. This virus was detected as a mixed infection with WMV in a jacko-lantern pumpkin sample collected from St. Clair County (Table 1; Fig. 1). In 2005 and 2006, ToRSV was not detected in any sample assayed.

WMV. In 2004, WMV was detected in eight jack-o-lantern pumpkin samples collected from Adam, Cook, Madison, and St. Clair counties (Fig. 1). Single infection of WMV was detected in six samples. Mixed infection of WMV with ToRSV was detected in one sample and WMV with ZYMV in another sample (Table 1). In 2005, WMV was detected in 64 samples representing 28 counties (51\% of counties surveyed) throughout the state (Table 2; Fig. 3). WMV was identified as a singlevirus infection in 36 samples. Two-virus mixed infection of WMV and SqMV was detected in 21 samples, mixed infection of WMV and PRSV in two samples, and mixed infection of WMV and CMV in two samples. Mixed infection of three viruses of WMV with PRSV and SqMV was detected in two samples and WMV with ZYMV and SqMV was detected in one sample. In 2006, WMV was detected in 89 samples from 37 counties ( $79 \%$ of counties surveyed) throughout the state (Fig. 4). Single-virus infection was detected in 30 samples (Table 3). Mixed infection of two viruses, WMV and SqMV, was identified in 50 samples (29\% of samples tested); WMV and CMV were detected in two samples, WMV and PRSV were detected in one sample, and WMV and ZYMV were detected in two samples. Three-virus infection of WMV with PRSV and ZYMV was detected in one sample, mixed infection of WMV with SqMV and ZYMV in two samples, and mixed infection of WMV with SqMV and CMV was detected in one sample (Table 3).

ZYMV. ZYMV was detected in three jack-o-lantern pumpkin samples in 2004, which were collected from Adams, Champaign, and Iroquois counties (Fig. 1). Single-virus infection of ZYMV was detected in one sample. Two-virus mixed infection of ZYMV with PRSV and ZYMV with WMV was detected in one sample each (Table 1). In 2005, ZYMV was detected in five samples collected from Champaign and McHenry counties in the northeastern region and Adams County in the south- western region (Table 2; Fig. 3). Singlevirus infection of ZYMV was recorded in three samples. Three-virus mixed infection of ZYMV, SqMV, and WMV was identified in one sample; and four-virus mixed infection of ZYMV, CMV, SqMV, and PRSV was detected from another sample (Table 2). In 2006, ZYMV was detected in six samples collected from Champaign and Kankakee counties in the northeastern region and Clay County in the southeastern region (Fig. 4). Single-virus infection of ZYMV was detected in one sample. Mixed infection of ZYMV with WMV was detected in two samples, three-virus infection of ZYMV with WMV and SqMV was detected in two samples, and three-virus infection of ZYMV with PRSV and WMV was detected in one sample (Table 3 ).

SLCV. None of the 88 samples tested during 2005 and 2006 was found positive for SLCV, indicating that SLCV did not exist in pumpkin or squash fields in Illinois.

Incidence of virus infection during the growing season. Single-virus infections mainly were detected earlier in the growing seasons (July and early August). The mixed infections were more common from the second week of August until the end of the growing season in October, when two to four viruses were detected in the same plant or in the same field. In Kankakee County (northern Illinois), the infection by the unknown potyviruses was detected in jack-o-lantern pumpkin samples in the first week of August. Similarly, single-virus infection of WMV was detected in squash samples in August in Kankakee County. Two-virus infection of the unknown potyviruses with SqMV was detected in September in this county. In Champaign County (central Illinois), three-virus mixed infection of WMV, PRSV, and SqMV was detected from jack-o-lantern pumpkin and squash fields in September. The jack-olantern pumpkin and squash samples from Gallatin County (southern Illinois) had single-virus infection with SqMV in early August, whereas jack-o-lantern pumpkin samples collected in September from Gallatin County showed two-virus mixed infection of WMV with SqMV.

Symptomatology. Most of the viruses detected during the surveys produced similar symptoms on pumpkin, squash, and gourd plants because the same virus produced a wide range of symptoms on different cultivars. Common symptoms observed on the infected plants were light- and darkgreen mosaic, veinbanding, and veinclearing, sometimes accompanied by puckering or deformation of pumpkin and squash leaves. Severe symptoms on the leaves were fernleaf and shoestring with reduction of fruit size, deformed fruit, and color breaking of fruit.

The most common symptoms observed on leaves of squash and pumpkin infected with CMV was mosaic of green and light- green or yellow with curling. Severe symptoms caused by CMV included puckering of leaves with mosaic followed by fernleaf. The fruit exhibited galls, distortion, and reduction of size.

Severe mosaic of green and dark-green with leaf deformation and blistering was noticed on squash and pumpkin leaves infected with PRSV. Pumpkin leaves also exhibited veinbanding and veinclearing on leaves. The fruit on PRSV-infected plants showed color breaking.

ZYMV infection in pumpkin or squash plants usually was associated with severe symptoms of green and dark-green mosaic and upward curling of leaves. Veinbanding, fernleaf, and shoestrings also were associated with ZYMV infection in squash and pumpkin. Squash plants infected with ZYMV produced fruit with color-breaking symptoms. The general symptoms associated with the unidentified potyviruses were mild mosaic, veinbanding, fernleaf, and reduction of leaf size. Plants infected with TRSV exhibited mild yellow mosaic, crinkling, and thickening of leaves. Some plants also showed general yellowing of the leaves.

Mosaic of light green and dark green with thickening of leaves and crinkling or slight puckering was associated with SqMV on pumpkin and squash. In severely infected plants, shoestring and fernleaf symptoms were observed on jack-o-lantern pumpkin. SqMV also caused veinbanding, ringspot, blistering, and deformation on leaves. Color breaking on fruit was observed in squash plants infected with SqMV. WMV infection induced light- and dark-green mosaic with or without puckering and deformation on pumpkin and squash leaves. Severe symptoms of WMV infection on leaves included fernleaf symptom and veinbanding or veinclearing on jack-o-lantern pumpkin. Deformation and galls were commonly evident on pumpkin fruit.

Testing for pathogenicity. Among the six viruses (CMV, PRSV, SqMV, TRSV, WMV, and ZYMV) tested for pathogenicity, only five (CMV, PRSV, SqMV, WMV, and ZYMV) caused symptoms in the inoculated plants and subsequently were detected in the inoculated plants using ELISA. Symptoms on CMV- and PRSVinoculated plants were noticed by the third week after inoculation on $C$. moschata Dickinson and $C$. pepo Howden and Grey Zucchini. Plants of all the cultivars inoculated with SqMV and ZYMV showed symptoms within 2 weeks after inoculation. WMV produced symptoms on leaves of inoculated plants in all four cultivars inoculated, beginning 2 weeks after inoculation.

Molecular diagnosis. The presence of TRSV, detected by ELISA, was confirmed by RT-PCR, which produced a product of $348 \mathrm{bp}$. This was the first time that TRSV was identified in pumpkin in Illinois. The 
presence of ToRSV could not be verified using RT-PCR due to the failure of the sample to produce a product of $609 \mathrm{bp}$, although the positive control produced the required PCR product of $609 \mathrm{bp}$. The unknown Potyvirus sp. also was not detected by RT-PCR using different primers.

\section{DISCUSSION}

WMV was the most prevalent virus in pumpkin and squash fields throughout the state; it was detected in 161 of 327 (49\%) jack-o-lantern pumpkin, squash, and gourd samples tested during the surveys. The results of this study are similar to findings reported from southern Illinois, where WMV was determined to be the most prevalent virus in jack-o-lantern pumpkin and squash fields (27).

SqMV was detected in more counties than any of the other viruses identified in pumpkin and squash fields in 2005 and 2006. SqMV is considered to be a seedborne pathogen and its wide incidence in Illinois was unexpected and was contrary to the report from southern Illinois (27), where SqMV was detected in only 5\% samples tested and as mixed infections with other viruses. The possible reasons for high incidence of SqMV in Illinois could be (i) its introduction to the fields by undetected infected seed (15) or (ii) its spread by cucumber beetles from overwintering weeds (8). Spotted cucumber beetle (Acalymma trivittatum) and striped cucumber beetle (Diabrotica undecimpunctata howardi) are known as the most important vectors for transmission of SqMV within a field and between neighboring crops or fields $(17,23)$. Both cucumber beetles were prevalent in pumpkin and squash fields in Illinois during sample collection.

The occurrence of CMV in pumpkin, squash, and gourd fields was confined to the northeastern region of the state, in Cook, Kane, McHenry, and Will counties in the Chicago metropolitan area. The only other county outside this region where CMV was detected was Madison County (southwestern region) that is a part of the St. Louis metropolitan area. Prior to this investigation, it was thought that CMV was one of the most prevalent viral diseases of cucurbits in Illinois. However, the findings of this study suggest that CMV may only overwinter in ornamental plants, which are grown extensively in the Chicago and St. Louis metropolitan areas, and spread from ornamental plants to nearby pumpkin and squash fields by aphids. Several ornamentals (e.g., peperomia, impatiens, and hibbertia) have been reported to be infected with CMV (7). More than 60 aphid species have been reported as vectors of CMV (18). In contrast to our findings in the pumpkin and squash fields, CMV was widely detected in the pepper fields in southern Illinois in 1999 (11). The investigators thought that CMV overwintered in solanaceous weeds from which it was transmitted to pepper plants. The reasons for widespread incidence of CMV in pepper fields in 1999 but not in pumpkin, squash, and gourd crops during 2004 to 2006 in southern Illinois may be (i) the strains of CMV infecting pepper and cucurbits are different or (ii) CMV is not widely prevalent in Illinois anymore.

PRSV was detected in some counties in northern and central Illinois. The only county from the south where PRSV was detected was Wayne County. This finding contradicts the report from southern Illinois (27), where PRSV was reported to be the second most prevalent virus detected during 1998 to 2000. A limited incidence of ZYMV in pumpkin and squash fields in this study is similar to the results reported from southern Illinois (27). This low incidence of ZYMV in pumpkin and squash fields in Illinois might be because there are only a few alternative hosts, including weeds, that are potential reservoirs or overwintering hosts for ZYMV (5).

Detection of potyviruses, with a serological property distinct from WMV, PRSV, or ZYMV was a new finding in Illinois. The symptoms produced by the unknown potyviruses were similar to the symptoms produced by other potyviruses infecting pumpkin and squash. Potyvirus spp., Clover yellow vein virus, WMVMorocco, and Zucchini yellow fleck virus, also have been reported to infect cucurbits (18). However, we were not been able to identify the detected unknown potyviruses using RT-PCR procedures. Further investigation is needed to accurately identify the unknown potyviruses in Illinois.

SLCV was not detected by ELISA during this study. It appears that this virus does not occur in Illinois; perhaps its geographic distribution is limited to the warmer areas of the south and southwestern United States, where the vector $\mathrm{Be}$ misia tabaci is more prevalent $(3,17)$.

TRSV was detected in central and northeastern Illinois. The virus was detected for the first time in Illinois (13). TRSV, however, has been reported in other cucurbit-producing areas in the United States, including Indiana and Wisconsin, which are neighboring states to Illinois (24). Because the virus was detected in only one survey and was identified from limited areas, it probably is not a serious viral disease of pumpkin or squash in Illinois at present. ToRSV was detected by ELISA in only one sample in 2004. The presence of this virus, however, could not be confirmed by RT-PCR, because the sample tested negative in PCR. This failure in detecting this virus by RT-PCR could have been due to the fact that the sample was stored at $-20^{\circ} \mathrm{C}$ and the viral RNA might have deteriorated during the storage. Because ToRSV was detected in only a single sample during the 3-year survey, it is not among the important viral diseases of pumpkin and squash in Illinois at present.

The percentage of samples with mixedvirus infection was 18,25 , and $48 \%$ in 2004, 2005, and 2006, respectively. Dual infection of WMV and SqMV was found to be the most prevalent mixed infection detected. Mixed virus infections in pumpkin, squash, and gourds can lead to enhanced symptoms, leading to higher crop losses than single-virus infections, as observed in zucchini squash infected with ZYMV and CMV (6). This increase has been attributed to the higher rate of replication of CMV in cells with Potyvirus spp. due to the suppression of posttranscriptional gene silencing (20). Synergism of comoviruses (Cowpea mosaic virus or Bean pod mottle virus) with Soybean mosaic virus (SMV) of the Potyvirus group also has been reported, wherein the titers of the comoviruses were enhanced in the presence of SMV (1).

During this study, we tried to determine if there were relationships between individual viruses detected and symptoms on pumpkin, squash, or gourd plants. We found that CMV, PRSV, SqMV, TRSV, WMV, and ZYMV produced similar symptoms in single and mixed infections in all host plants studied. Our observations agree with the previous reports $(4,23)$ that single or mixed infection of two or more viruses in cucurbits produce similar symptoms. It could be concluded from our studies, as well as from the previous reports, that viral diseases of cucurbits cannot be identified reliably from each other based on the disease symptoms, and molecular methods (e.g., ELISA or PCR) should be employed for accurate identification of cucurbit viruses.

In this study, $89 \%$ of processing pumpkin samples tested negative for viruses. The studies in the greenhouse also indicated a low disease severity on inoculated C. moschata Dickinson, which is the most common cultivar grown in Illinois. These results indicated that $C$. moschata Dickinson is resistant to the known viruses and may be used as a source of resistance in breeding pumpkin and squash to produce cultivars resistant or tolerant to viral diseases. This finding agrees with the previous findings of resistance to ZYMV and WMV in C. moschata $(10,19)$.

This study provides information on the overall incidence of viruses in pumpkin, squash, and gourd crops in Illinois, which could help to develop effective strategies for management of viral diseases in cucurbit fields. However, more investigations are needed to identify possible strains of the identified viruses, determine alternative crops and weeds that serve as overwintering hosts for WMV and SqMV, and determine the synergism or antagonism among the viruses in cucurbits. There is also a need for research to investigate the importance of seed transmission and the role of 
different insects in spreading these viruses among pumpkin, squash, and other cucurbits in the fields.

\section{ACKNOWLEDGMENTS}

This research was supported in part by funds from the Illinois Department of Agriculture (Project No. SA 06-101) and the North Central RegionSustainable Agriculture Research and Education (Project No. GNC05-047). We thank all of the extension personnel in Illinois who assisted us in the sample collections.

\section{LITERATURE CITED}

1. Anjos, J. R., Jarlfors, U., and Ghabrial, S. A. 1992. Soybean mosaic potyvirus enhances the titer of comoviruses in dually infected soybean plants. Phytopathology 82:17-23.

2. Babadoost, M., and Islam, S. Z. 2003. Fungicide seed treatment effects on seedling damping-off of pumpkin caused by Phytophthora capsici. Plant Dis. 87:63-68.

3. Cohen, S., Duffus, J. E., Larsen, R. C., Liu, H. Y., and Flock, R. A. 1983. Purification, serology and vector relationships of Squash leaf curl virus, a whitefly-transmitted geminivirus. Phytopathology 73:1669-1673.

4. Davis, R. F., and Muzuki, M. K. 1987. Detection of cucurbit viruses in New Jersey. Plant Dis. 71:40-44.

5. Desbiez, C., and Lecoq, H. 1997. Zucchini yellow mosaic virus. Plant Pathol. 46:809-829.

6. Fattouh, F. A. 2003. Double infection of cucurbit host by Zucchini yellow mosaic virus and Cucumber mosaic virus. Pakistan J. Plant Pathol. 2:85-90.

7. Flasinski, S., Scott, S. W., Barnett, O. W., and Sun, C. 1996. Disease of peperomia, impatiens, and hibbertia caused by Cucumber mosaic virus. Plant Dis. 79:843-848.

8. Freitag, J. H. 1956. Beetle transmission, host range, and properties of Squash mosaic virus. Phytopathology 46:73-81.
9. Gibbs, A., and Mackenzie, A. 1997. A primer pair for amplifying part of the genome of all potyvirids by RT-PCR. J. Gen. Virol. 63:9-16.

10. Gilbert-Albertini, F., Lecoq, H., Pitrat, M., and Nicolet, J. L. 1993. Resistance of Cucurbita moschata to Watermelon mosaic virus type 2 and its genetic relation to resistance to $\mathrm{Zuc}$ chini yellow mosaic virus. Euphytica 69:231237.

11. Hobbs, H. A., Eastburn, D. M., D'Arcy, C. J., Kindhart, J. D., Masiunas, J. B., Voegtlin, D. J., Weinzierl, R. A., and McCoppin, N. K. 2000. Solanaceous weeds as possible source of Cucumber mosaic virus in Southern Illinois for aphid transmission to pepper. Plant Dis. 84:1221-1224.

12. Hughes, P. L., and Scott, S. W. 2003. First report of Tomato ringspot virus in Butterfly Bush (Buddleia davidii). Plant Dis. 87:102.

13. Jossey, S., and Babadoost, M. 2006. First Report of Tobacco ringspot virus in Pumpkin (Cucurbita pepo) in Illinois. Plant Dis. 9:1361.

14. Marie-Jeanne, V., Ioos, R., Peyre, J., Alliot, B., and Signoret, P. 2000. Differentiation of Poaceae potyviruses by reverse transcriptionpolymerase chain reaction and restriction analysis. J. Phytopathol. 148:141-151.

15. McLean, D. M., and Meyer, H. M. 1961. A survey of cucurbit viruses in the lower Rio Grande Valley of Texas: preliminary report. Plant Dis. Rep. 45:137-139.

16. McLeod, P. J., Scott, H. A., and Morelock, T. E. 1986. Zucchini yellow mosaic virus: a new severe cucurbit disease. Ark. Farm Res. 35:2

17. Nameth, S. T., Dodds, J. A., Paulus, A. O., and Laemmlen, F. F. 1986. Cucurbit viruses of California: an ever changing problem. Plant Dis. 70:8-11.

18. Provvidenti, R. 1996. Diseases caused by virus Page 37-45 in: Compendium of Cucurbit Diseases. T. A. Zitter, ed. American Phytopathological Society, St. Paul, MN.

19. Provvidenti, R., Gonsalves, D., and Humay- dan, H. S. 1984. Occurrence of Zucchini yellow mosaic virus in cucurbit for Connecticut, New York, Florida, and California. Plant Dis. 68:443-446.

20. Pruss, G., Ge, X., Shi, X. M., Carrington, J. C., and Vance, V. B. 1997. Plant viral synergism the potyviral genome encodes a broad-range pathogenicity enhancer that transactivates replication of heterologous viruses. Plant Cell 9:859-868.

21. Rabenstein, F., Seifers, D. L., Schubert, J., French, R., and Stenger, D. C. 2002. Phylogenetic relationships, strain diversity and biogeography of tritimoviruses. J. Gen. Virol. 83:895-906.

22. Sammons, B., and Barnett, O. W. 1987. Tobacco ringspot virus from squash grown in South Carolina and transmission of the virus through seed of smooth pigweed. Plant Dis. 71:530-532.

23. Sammons, B., Barnett, O. W., Davis, R. F., and Mizuki, M. K. 1989. A survey of viruses infecting yellow summer squash in South Carolina. Plant Dis. 73:401-404

24. Sinclair J. B., and Walker J. C. 1956. A survey of ring spot on cucumber in Wisconsin. Plant Dis. Rep. 40:19-20.

25. Tairo, F., Mukasa, S. B., Jones, R. A. C., Kullaya, A., Rubaihayo, P. R., and Valkonen, J. P. T. 2005. Unravelling the genetic diversity of the three main viruses involved in sweet potato virus disease (SPVD), and its practical implications. Mol. Plant Pathol. 6: 199-211.

26. Ullman, D. E., Cho, J. J., and German, T. L. 1991. Occurrence and distribution of cucurbit viruses in the Hawaiian Islands. Plant Dis. 75:367-370.

27. Walters, S. A., Kindhart, J. D., Hobbs, H. A., and Eastburn, D. M. 2003. Viruses associated with cucurbit production in southern Illinois. HortScience 38:65-66.

28. Webb, R. E. 1971. Watermelon mosaic virus and 2 in squash on the Atlantic seaboard. Plant Dis. Rep. 55:132-135 